\title{
Essential Oil Composition of Thymus fallax From Adıyaman (Turkey)
}

\author{
Omer Kilic (Corresponding aouthor) \\ Adiyaman University, Pharmacy Faculty, Adiyaman, Turkey \\ E-mail: omerkilic77@gmail.com \\ Sinasi Yildirimli \\ Hacettepe University, Science Faculty, Ankara, Turkey
}

\begin{abstract}
Thymus fallax Fisch. \& Mey. is a native plant belongs to Lamiaceae family; which can use in ethnobotany, modern medicine, aromateraphy and in different industries for its essential oils. In this study the essential oil components aerial parts of Thymus fallax was examined by GC-MS technique. Forty nine constituents were determined representing $92.6 \%$ oil. The main compounds and chemotypes of studied sample were carvacrol $(24.3 \%)$, thymol (8.9\%), $\alpha$-terpineol $(6.9 \%)$, borneol $(6.4 \%)$ and carveol $(6.2 \%)$. With this study, chemotypes of studied taxa were detected carvacrol and thymol. Studied plant samples were found to be rich in respect to essential oils and the results discussed in terms of natural product.
\end{abstract}

Key words: Thymus, essential oil, thymol, carvacrol, natural products.

DOI: $10.7176 / \mathrm{JSTR} / 6-08-10$

\section{Introduction}

Plants have been employed in conventional medicine since ancient times, particularly due to their antimicrobial activity, and their aromatic, medicinal properties have consequently been the object of frequent scientific researches (Edrir, 2007). According to the world health organization, about threequarters of the world population rely upon traditional remedies for their health care. "Fresh and dried aromatic plants as well as their processed products have been widely used as flavourings since ancient times, however, during last few decades they also have become a subject for a search of natural antioxidants and antibacterial agents" (Li et al., 2008). "Thymus L. belonging to the Lamiaceae family, is a pleasant smelling perennial shrub, which grows in several regions of the world such as Western Mediterranean, Iran, and Turkey" (Baytop, 1997). "Thyme is used for seasoning, poultry, soups, and vegetables in herbal teas prepared for colds and flues as well. Thyme and its oil have been used as fumigants, antiseptics, antioxidants, and mouth washes" (Gulluce et al., 2007). Among the aromatic plants belonging to the family Lamiaceae, the genus Thymus is noteworthy for the numerous species and varieties of wild-growing plants, and thyme oils present high antimicrobial effect compared to the oils of other plants. The oils of Thymus taxa are widely used as an antiseptic agent in many pharmaceutical preparations and as a flavouring agent for many kinds of food products and their essential oil compositions have been studied earlier (Bagci et al., 2005; Tümen et al., 1999).

The genus Thymus is represented in Turkey more than 60 taxa, 20 of which endemic. Members of this genus are called "kekik" in Turkish and most widely used as spices and in traditional folk medicine to treat infectious diseases and disorders (Gümüş, 2010). In Turkey, medicinal and aromatic plants widely distributed and there are rich and diversified floras; these economically important plants have recognition for nutritional and medicinal characteristic; besides they are used in various industries such as cosmetics, perfumes, detergents, as well as in pharmacology and food flavoring (Çalmaşur et al., 2006). Thymus is a well known genus in the Lamiaceae family; this genus is generally used as traditional remedy to treat various ailments such as a antimicrobial, insecticides, antifungal, herbicidal repellents, expectorant carminative and aromatic for whooping and convulsive coughs, digestive disorders and menstrual problems sedative, anesthetic, antiseptic, abortifacient, antirheumatic (Hussain, 2009). About 3000 essential oils produced by at least 2000 plant species, which about 300 of them are significant from the marketing viewpoint (Hussain, 2009). Essential oils and their constituent small molecules exhibit excellent medicinal properties and hence may be used against infectious and noninfectious diseases (Raut

92 | $P$ a g e

www.iiste.org 
\& Karuppayil, 2014). Essential oils are definite as any volatile oil[s] that have strong aromatic components and that give characteristic odor, flavor, or smell to a plant. These are the byproducts of plant metabolism and are frequently referred to as volatile plant secondary metabolites. Essential oils are found in glandular hairs or secretory cavities of plant-cell wall and are present as droplets of juice in the leaves, stems, bark, flowers, roots, and/or fruits in different plants (Koul et al., 2008).

Secondary metabolites, especially essential oils play important ecological and biological roles and are important for plant defense as they often contain antimicrobial, antifungal and antioxidative properties (Najafian, 2014). Essential oils have been widely employed for centuries in the pharmaceutical, agricultural, hygienic, and cosmetic industries and have been added to foods as spices or herbs (Zhang et al., 2015). Essential oils may be affected by a variety of factors including nutrition, habitat, soil, solar radiation, temperature, humidity, location, genetics, and harvesting time (Lozione \& Venskutonis, 2005). One of the most important genera of the Lamiaceae family is Thymus L. taxa are herbaceous, perennial, small shrubs usually growing in light soils containing calcium compounds (Llorens et al., 2014). In the most parts of the world Thymus are considered most valuable taxa and food preservatives in the food industry; it has been widely used for its carminative, digestive, antispasmodic, anthelmintic, bactericidal, secretomotor, antitussive, antimicrobial, antiinflammatory, and expectorant effects (Nabavi et al., 2015). Research has shown that the most crucial factor for determining thyme chemotypes is the amounts of thymol and carvacrol (Pitarokili et al., 2014). Essential oils may be found in all of the aromatic plant species organs, serving important roles such as the protection of the plant against microorganisms, insects, and herbivorous animals or the attraction of insects responsible for the dispersion of pollens and seeds (Pauli, 2006). T. fallax is distributed in Iran and Turkey; it is an erect, branching dwarf shrub with lanceolate elliptic leaves covered by numerous wine-colored glands; white-topurple flowers are arranged in a loose head inflorescence. Thymus taxa are characterized by having an excellent richness in essential oil; many of the Thymus oils have germicidal, antibacterial; as well as for stimulating digestion, clear thinking, circulation, and mental balance; many other species of the genus Thymus have also been studied for their composition and antibacterial activity (Costa et al., 2015).

In this study we aimed to determine essential oil composition and to determined chemotypes and to potential usefulness of Thymus fallax. From the analysis results; it is understood that this plant is rich in essential oil amount and various chemical content. With this study, the essential oil yield and composition of the aboveground parts of this plant species were determined and important results were obtained for the multi-purpose use of this plant.

\section{Materyal ve Metod}

Thymus fallax was collected from between Koçali village and Çelikhan district, stony slopes, 1700-1750 m., in June 2017, K1lıc 5242. Plant sample was identified with 7 volume of Flora of Turkey (Davis, 1982), by plant taxonomist Ö.Kılıç. The voucher specimen have been deposited in the Pharmacy Faculty of Adıyaman University.

The essential oil was isolated by hydro distillation of air-dried samples using a Clevenger-type apparatus for $3 \mathrm{~h}$, according to the method recommended in British Pharmacopoeia. The distillated oils were dried over anhydrous sodium sulfate and stored in tightly closed dark vials at $4^{\circ} \mathrm{C}$ until analysis. A Varian 3800 gas chromatograph interfaced with a Varian 2000 ion trap mass spectrometer was used. Injector temperature, $260^{\circ} \mathrm{C}$; injection mode, splitless; column, $60 \mathrm{~m}$, CP-Wax $52 \mathrm{CB} 0.25 \mathrm{~mm}$ i.d., $0.25 \mathrm{~lm}$ film thickness. The oven temperature was programmed $45^{\circ} \mathrm{C}$ held for $5 \mathrm{~min}$, then increased to $80{ }^{\circ} \mathrm{C}$ at a rate of $10^{\circ} \mathrm{C} / \mathrm{min}$, and to $240{ }^{\circ} \mathrm{C}$ at $2{ }^{\circ} \mathrm{C} / \mathrm{min}$. Helium used as carrier gas was at a constant pressure of $10 \mathrm{psi}$; the transfer line temperature $250^{\circ} \mathrm{C}$; the ionisation mode, electron impact; acquisition range, $40-200 \mathrm{~m} / \mathrm{z}$; scan rate, 1 us $^{-1}$. The compounds were identified using the National Institute of Standards and Technology library, mass spectral library and verified by the retention indices. The relative retention index were calculated on the basis of peak-area ratios. The essential oil composition of studied sample was showed in Table 1.

\section{Results and Discussion}

Although some researches about different Thymus taxa (Sökmen et al., 2004); however, only a few studies have been carried out with T. fallax. In this study, essential oil composition aerial parts of Thymus fallax was investigated and carvacrol (24.3\%), thymol (8.9\%), $\alpha$-terpineol $(6.9 \%)$, borneol (6.4\%) and carveol (6.2\%) were detected the main constituents of T. fallax (Table 1). GC-MS analysis of the essential oils from aerial parts of Thymus migricus, Thymus fallax and Thymus pubescens var. pubescens were analyzed and the major components in the essential oil of $T$. migricus were found to be $a$-terpineol (30.6\%), thymol (20.7\%); while in the essentiol oil of T. fallax cis-carveol (29.6\%) and $a$-terpineol (10.8\%); carvacrol was a dominant compound with a percentage $66.1 \%$ of the essential oil of $T$.

93 I P a g e 
pubescens var. pubescens (Küçükbay et al., 2014); similarly $\alpha$-terpineol (6,9\%) and and carveol (6.2\%) were the major compounds in this research (Table 1). According to GC/MS results of the essential oil of T. fallax carvacrol (68.1\%), $p$-cymene $(4.8 \%), \beta$-caryophylene $(3.8 \%)$, and $\gamma$-terpinene $(3.6 \%)$ were the main constituents of the oil. In this study, we were detected 49 compounds representing (92.6\%) of the oil and carvacrol $(24.3 \%)$, thymol (8.9\%), $\alpha$-terpineol $(6,9 \%)$, borneol $(6.4 \%)$ and carveol $(6.2 \%)$ were found to be the main constituents (Table 1). In another study, carvacrol (69.2\%), p-cymene (15.4\%), thymol $(5.3 \%)$ and $\gamma$-terpinene $(4.5 \%)$ were identified the main constituents of $T$. fallax from Iran (Rustaiee et al., 2011); wehereas in our study $p$-cymene $(2.8 \%)$, and $\gamma$-terpinene $(0.8 \%)$ were identified ony low amounts (Table 1). It is thought that diverse results found in the literature is caused differences in climatic and geographical conditions, developmental stages, the existence of different varieties of chemotypes T. fallax, the extraction method of the oils and/or all of them. Carvacrol and thymol are the major constituents of the essential oils, which belong to the Lamiaceae family of plants including oregano and thyme (Daferera et al., 2002). 
Table 1. Essential oil composition of Thymus fallax

\begin{tabular}{|c|c|c|}
\hline Components & Relative Retention Index & Thymus fallax (\%] \\
\hline Tricyclene & 929 & 0.2 \\
\hline$\alpha$-Thujene & 932 & 1.1 \\
\hline$\alpha$-Pinene & 941 & 1.0 \\
\hline Camphene & 956 & 0.2 \\
\hline Sabinene & 978 & 0.1 \\
\hline$\beta$-Pinene & 982 & 0.4 \\
\hline 3-Octanone & 986 & 0.2 \\
\hline Myrcene & 993 & 1.9 \\
\hline 3-Octanol & 995 & 0.5 \\
\hline$\alpha$-Phellandrene & 1005 & 0.7 \\
\hline$\delta$-3-Carene & 1012 & 2.1 \\
\hline$\alpha$-Terpinene & 1018 & 1.6 \\
\hline$p$-Cymene & 1026 & 2.8 \\
\hline Limonene & 1031 & 0.5 \\
\hline 1,8-Cineole & 1035 & 4.4 \\
\hline$\gamma$-Terpinene & 1062 & 0.8 \\
\hline Linalool oxide & 1089 & 0.3 \\
\hline Terpinolene & 1091 & 1.2 \\
\hline Linalool & 1099 & 2.1 \\
\hline Limonene oxide & 1139 & 0.3 \\
\hline trans-Sabinol & 1143 & 0.5 \\
\hline Camphor & 1147 & 1.5 \\
\hline cis-Chrysanthenol & 1166 & 0.3 \\
\hline Borneol & 1172 & 6.4 \\
\hline Terpinen-4-ol & 1179 & 1.0 \\
\hline$\alpha$-Terpineol & 1191 & 6.9 \\
\hline Pinocarvone & 1195 & 0.2 \\
\hline Geraniol & 1255 & 4.6 \\
\hline Carveol & 1291 & 6.2 \\
\hline Thymol & 1293 & 8.9 \\
\hline Carvacrol & 1300 & 24.3 \\
\hline Eugenol & 1360 & 0.4 \\
\hline$\beta$-Copaene & 1378 & 0.2 \\
\hline Geranyl acetate & 1383 & 1.0 \\
\hline$\beta$-Bourbonene & 1389 & 0.3 \\
\hline Aromadendrene & 1443 & 0.2 \\
\hline$\alpha$-Humulene & 1457 & 0.1 \\
\hline Y-Muurolene & 1479 & 0.1 \\
\hline Germacrene D & 1482 & 1.8 \\
\hline$\gamma$-Amorphene & 1498 & 0.1 \\
\hline$\beta$-Bisabolene & 1508 & 0.4 \\
\hline$\gamma$-Cadinene & 1517 & 1.8 \\
\hline trans-Calamenene & 1531 & 0.3 \\
\hline Spathulenol & 1579 & 0.7 \\
\hline Caryophyllene oxide & 1584 & 1.5 \\
\hline Aromadendrene & 1643 & 0.1 \\
\hline$\alpha$-Cadinol & 1657 & 0.1 \\
\hline$\beta$-Bisabolol & 1678 & 0.2 \\
\hline$\alpha$-Cadinene & 1541 & 0.1 \\
\hline Total identified components: 49 & & 92.6 \\
\hline
\end{tabular}


Several in vitro and in vivo researched showed different bioactivity of carvacrol nutrient, including antibacterial, antioxidant, antiseptic, antispasmodic, antifungal, antiviral, anti-inflammatory, expectorant, antitussive, immunomodulatory and chemopreventive as well as modifier of rumen microbial fermentation and reduction of methane emission (Bravo et al., 2014). Carvacrol has crucial bioactivities on poultry and animal physiology and metabolism, this compound could have antioxidant action on poultry meat when added in the diet. Bavadekar (2012) reported that carvacrol promotes cell death in prostate cancer cells. "Several studies have been reported the addition of some phytogenic additives or their products such as cold pressed oil, essential oil or extracts to animal and poultry diets that improved live body weight, body weight gain, feed conversion ratio, immune response, antioxidant status, carcass traits and quality, and lowered morbidity and mortality rates" (Dhama et al., 2015). Thymol have antioxidant, antispasmodic, antiseptic, antimicrobial, and anti-inflammatory properties; some studies have reported the usage of thymol for anticancer property (Andersen, 2005). The antioxidant effects of thymol and carvacrol have been confirmed in several studies, suggesting their administration as nutritious elements in the improvement of novel functional foods (Rubio et al., 2013). Thymol protective nature against caries and plaques allures the field of dental drugs (Chauhan et al., 2014).

The current review covers important aspects including the essential oil composition, potential usefulness and carvacrol, thymol richness of Thymus fallax.

\section{Acknowledgments}

The authors thanks the financial support from the Adiyaman University Scientific Research Project Unit, Adiyaman/Turkey, Project no. ECZFMAP/2019-0004.

\section{References}

Edrir, A.E. (2007). Pharmaceutical and therapeutic potentials of essential oils and their individual volatile constituents: A review. Phytotheraphy Research, 21: 308-323.

Li, HB. Wong, CC. Cheng, KW. \& Chen, F. (2008). Antioxidant properties in vitro total phenolic contents in methanol extracts medicinal plants. Food Science Technology, 41: 385-390.

Baytop, T. (1997). Turkce Bitki Adlari Sozlugu (A dictionary of vernacular names of wild plants of Turkey), Ankara. Publication of the Turk Dil Kurumu. No.: 578.

Gulluce, M. Sahin, F. Sokmen, M. Ozer, H. Daferera, D. Sokmen, A. Polissiou, M. Adiguzel, A. \& Ozkan, H. (2007). Antimicrobial and antioxidant properties of the essential oils and methanol extract from Mentha longifolia. Food Chemistry, 103: 1449-1456.

Bagci, E. Husnu, K. \& Baser, C. (2005). Study of the essential oils of Thymus haussknechtii Velen and Thymus kotschyanus taxa from the eastern Anatolian region in Turkey. Journal Flavour Fragrance, 20: 199-202.

Tümen, G. Yıldız, B. Kirimer, N. Kürkcüoğlu, M. \& Başer, KHC. (1999). Composition of the Essential Oil of Thymus fallax from Turkey. Journal Essential Oil Research, 11: 489-490

P.H. Davis. (1982). Flora of Turkey and the East Aegean Islands. Vol.7. 349-382.

Gumus, T. (2010). Determination of the changes of antifungal properties of Satureja hortensis, Thymus vulgaris and Thymbra spicata exposed to gamma irradiation. Radiat. Physology Chemistry, 79: 109-114. 
Çalmaşur, O. Aslan, İ. Şahin, F. (2006). Insecticidal and Acaricidal Effect of Three Lamiaceae Plant Essential Oils Against Tetranychus urticae and Bemisia tabaci Genn., Industrial Crops and Products, 23: 140-146.

Hussain, AI. (2009). Characterization and biological activities of essential oils of some species of Lamiaceae. Faisalabad: University of Agriculture; 2009.

Raut, JS. Karuppayil, SM. (2014). A status review on the medicinal properties of essential oils. Industrial Crops Products, 62: 250-264.

Koul, O. Walia, S. Dhaliwal, G. (2008). Essential oils green pesticides: potential and constraints. Biopestic, 4: 63-84

Najafian, S. (2014). Storage conditions affect the essential oil composition of cultivated Balm Mint Herb (Lamiaceae) in Iran. Industrial Crops and Products, 52; 575-581.

Zhang, DY. Yao, XH, Duan, MH. Wei, FY. Wu, GH. Li, L. (2015). Variation of essential oil content and antioxidant activity of Lonicera species in different sites of China. Industrial Crops and Products, 77; 772-779.

Lozione, K. Venskutonis, P.R. (2005). Influence of environmental and genetic factors on the stability of essential oil composition of Thymus pulegioides. Biochemical Systematics and Ecology, 33: $517-525$.

Llorens, L. Llorens-Molina, JA. Agnello, S. \& Boira, H. (2014). Geographical and environmentrelated variations of essential oils in isolated populations of Thymus richardii in the Mediterranean basin. Biochemical Systematics and Ecology, 56: 246-254.

Nabavi, SM. Marchese, A. Izadi, M. Curti, V. Daglia, M. Nabavi, SF. (2015). Plants belonging to the genus Thymus as antibacterial agents: From farm to pharmacy. Food Chemistry, 173: 339-347.

Pitarokili, D. Constantinidis, T. Saitanis C, Tzakou O. (2014). Volatile compounds in Thymus sect. teucrioides (Lamiaceae): Intraspecific and interspecific diversity, chemotaxonomic significance and exploitation potential. Chemistry \& Biodiversity, 11: 593-618.

Pauli, A. (2006). Anticandidal low molecular compounds from higher plants with special reference to compounds from essential oils. Medical Research Review, 26: 223-268.

Costa P, Medronho B, Gonçalves S, Romano A. (2015). Cyclodextrins enhance the antioxidant activity of essential oils from three Lamiaceae species. Industrial Crops and Products, 70: 341346.

Sokmen, A. Gulluce, M, Akpulat HA, Tepe B, Sokmen M, Şahin F. (2004). The in vitro antimicrobial and antioxidant activities of the essential oil and various extracts of Thymus eigii. Journal of Agricultural and Food Chemistry, 52: 1132-1137.

Küçükbay, FZ. Kuyumcu, E. Çelen, S. Azaz, AD. Arabacı T. (2014). Chemical Composition of the Essential Oils of Three Thymus Taxa from Turkey with Antimicrobial and Antioxidant Activities. Record Natural Product, 2: 110-120.

Rustaiee, AR. F. Sefidkon, I. Saeedi, Rasouli M. (2011). Aromatic Profile of Thymus fallax. Essential Oil Growing Wild in Iran. Jeobp, 14 (6): 782 - 785. 
Daferera, DJ. Tarantilis, PA. Polissiou, MG. (2002). Characterization of essential oils from Lamiaceae species by Fourier transform Raman spectroscopy. Journal Agriculture Food Chemistry, 50: 5503-5507.

Bravo, D. Pirgozliev, V. Rose, SP. (2014). A mixture of carvacrol, cinnamaldehyde, and capsicum oleoresin improves energy utilization and growth performance of broiler chickens fed maizebased diet. Journal Animal Science, 92: 1531-1536.

Bavadekar S. http://www.liu.edu/Brooklyn/Press-Releases./BK-PRApr25-2012.aspx. 2012.

Dhama, K. Shyma, K. Latheef, Saminathan, M. Abdul Samad, H, Karthik K, Tiwari R, Khan RU, Alagawany M, Farag MR, Alam GM, Laudadio V, Tufarelli V. (2015). Multiple beneficial applications and modes of action of herbs in poultry health and production-A review. International Journal Pharmacology, 11: 152- 176.

Andersen, A. (2005). Final report on the safety assessment of sodium pchloro-m-cresol, p-chloro-mcresol, chlorothymol, mixed cresols, m-cresol, o-cresol, p-cresol, isopropyl cresols, thymol, ocymen-5-ol, and carvacrol. International Journal Toxicology, 25: 29-127.

Rubio, L. Motilva, MJ. Romero, MP. (2013). A a review of the most effective antioxidant and antiinflammatory active principles. Crit Rev Food Science Nutrition, 53: 943-953.

Chauhan, AK. Jakhar, R. Paul, S. Kang, SC. (2014). Potentiation of macrophage activity by thymol through augmenting phagocytosis. Int Immunopharmacology, 18:340-346. 